\title{
THE SHIP AND THE STRANGER: A METAPHORICAL APPROACH TO GOVERNANCE AND ISLAM
}

\author{
Chaiwat Satha-Anand*
}

\begin{abstract}
Relying on a metaphorical approach aiming to produce effects which could change the ways the world is seen and conducive to freeing the Muslims from restrictive and conventional religious understanding, this article chooses to discuss the issues of governance and Islam by using the metaphors of 'the ship' and 'the stranger'. It argues that both help illuminate the idea of 'soft governance' in Islam, understood as an attempt to meaningfully connect a multiplicity of actors from different terrains with complex relationships among them in the process of governing with a much more pluralistic conceptualisation of power.
\end{abstract}

\section{Introduction}

Back in March 2006, a two-day seminar on 'Islam and Peace' was held at Bangkok's Thammasat University. It was organised by the Muslim Students Association and the National Reconciliation Commission, an independent body set up by the former Thai Prime Minister Thaksin Shinawatra to find ways to put an end to violence and bring about lasting peace in predominantly Muslim Southern Thailand. During that event, the chairperson of the National Economic and Social Advisory Council (NESAC) - himself a human-rights advocate - asked how Muslims would feel about the death sentence passed on those who commit apostasy from Islam. From among the audience - Muslim students from all over the country - a young man (dressed in white, with a skull-cap and a full beard) answered: "Such a punishment could not be considered to be violent." The NESAC chair persisted by saying that as - a non-Muslim - he could not understand this because there are different Muslim countries which deal with this issue differently. Some people might even consider the abandonment of one's faith as a form of freedom of religion and as such a purely personal matter. There were two reactions from the audience. The young man replied

* Chaiwat Satha-Anand is Professor of Political Science at Thammasat University, Bangkok. This contribution is a revised version of a paper that was published under the same title in the American Journal of Islamic Social Sciences 25, no. 4 (Fall 2008), 90-107. 
to the effect that the punishment in this world would be considered 'light' compared to what lies in the hereafter, and that those who suffer in this life will fare better in the next. He serenely added that the carrying out of such a punishment would depend on the strength of faith in Islam in different countries. Those with weak faith might not be prepared to pass such a judgment. At this point, a man standing in the back - and obviously frustrated by the question - suggested that this is 'too complicated an issue' and that Muslims should better listen to the learned.

The above-mentioned case is important for four related reasons. First, it points directly to the issue of Islam and governance, specifically in terms of a clash between a belief in the totality of life and the space for freedom of religion - generally understood as including a freedom to leave the faith. Second, and perhaps more importantly, it points to a highly contentious problem of governance: that of the power of the state and its limits to use punishment to uphold its desirable political society. Third, it also points to the way in which many Muslims might choose to ask 'religious experts' when facing a difficult problem on the road of Islamic governance. A choice, no doubt, is justified by a particular reading of Islamic traditions. Fourth, I do not think that this is unique to the Thai scene. I am rather certain that something similar to this has already happened elsewhere. Although state persecution for conversion away from Islam is rare in many parts of the Muslim world, there are, however, at least 14 Muslim countries - among them Afghanistan, Iran, Pakistan and Saudi Arabia - which consider apostasy a crime punishable by death. ${ }^{1}$

Scholars have recently shown that there are a number of ways by which the relationship between Islam and governance can be studied. In Southeast Asia, the main discourse on Islam centres on various models for an Islamic state, often based on the shari 'ah as the one and only source of reference. Such an orientation on the $\operatorname{sharī}^{-} a h$, for instance, had been proposed by many in Malaysia's oppositional Pan-Malaysian Islamic Party (Parti Islam SeMalaysia or PAS). Others - such as Malaysia's former Mahathir administration, the Malaysian social movement ABIM or the Indonesian mass organisations Muhammadiyah or Nahdatul Ulama - opted for a gradual 'Islamisation' of society. ${ }^{2}$ On the other hand, a Malaysian Islamic movement inspired by a rare mix of 'global Sufism' and strict adherence to the shari' 'ah-Al-Arqam - which is based on local residential communities and institutions while promoting economic independence, mutual support, social service and extensive missionary activities through the use of their own schools, clinics, farms and factories, could also be seen as an experiment in alternative development and non-state governance. ${ }^{3}$

Using in the following a metaphorical approach with a special emphasis on the state and its monopoly of violence - notably its power to punish - I shall argue that the kind of governance that is needed for Muslims to maintain their Islamic 
inspirations should be 'soft governance'. I shall begin with a discussion of the need for such a metaphorical approach in examining the issue of governance and Islam. This will be followed by two particular metaphors that were chosen to reflect the issue of governance vis-à-vis Islam: 'the ship(s)' and 'the stranger(s)', as well as the reasons for choosing them shall be examined. Finally - situating this discussion in the context of a recent debate on how the future of religion is to be understood from a contested philosophical perspective - the ways in which these two metaphors illuminate the notion of 'soft governance' will be explored.

\section{The Metaphorical Approach}

Islamic $h u d \bar{u} d^{4}$ laws - containing contentious provisions for punishments of different crimes such as flogging, amputation of limbs, stoning to death - appear to be favoured by the governments of the two northern Malaysian states of Kelantan and Terengganu (ruled by the opposition). Zainah Anwar (a prominent Malaysian non-governmental organisation leader and activist) raises the question as to the reason behind the apparent tendency among certain religious authorities to codify "the most conservative opinion" into laws, although within Islam there exist different juristic positions on this issue. For instance, the most rigid view is the death sentence to all apostates. However, some Islamic jurists hold that the death sentence will be prescribed only when apostasy is accompanied by 'rebellion' against the Muslim community and its 'legitimate' leadership (whatever might be meant by that). Yet other Islamic jurists - including the Grand Shaykh of Al-Azhar in Cairo - maintain that, although apostasy is to be considered a great sin, a personal change of faith is not a capital offence and therefore merits no punishment whatsoever. It seems that whenever there is a contest for political power, 'Islamic credentials' are measured on the ground of severity of punishments imposed on those who supposedly transgress Islamic teachings that are understood by some as a "mindset frozen in seventh century Arabia and medieval jurisprudence". ${ }^{5}$ For ordinary Muslims (or at least the ignorant ones among them), on the other hand, these severe judgments were either accepted or tolerated due to their own fear or wrongly understood 'respect' for 'religious authorities' and a genuine sense from their part that they - the 'lay' men and women - are lacking the required knowledge on religious matters, thus choosing to remain silent. ${ }^{6}$

If this is indeed the case then there is a real need to find an approach that is conducive to freeing the Muslims from restrictive and conventional religious understanding, especially when exploring subjects such as Islam and governance. These are two very distinctive concepts, one with a sense of totality of life, while the other connotes a sense of governing process. Both originated from different times that are centuries apart from each other. The usual approaches of doctrinal exegesis 
of the term 'governance' from an Islamic perspective, or a historical exploration of this relationship will deepen one's understanding of the subject. However, it will probably not open up a space that would be necessary for innovative readings that are important for the contributions from the part of Muslims to the subject of governance which could be shared with others with different beliefs in the future.

In examining the issues of Islam and governance, an alternative suggested here is the metaphorical approach. In the original Classical Greek, $\mu \varepsilon \tau \alpha \varphi \rho \rho \alpha ́$, metaphorá, means 'transfer'. Contrary to the conventional belief according to which metaphors are used mainly in artistic or literary leanings, they are actually indispensable elements in the thought process of human beings because they serve as mechanisms through which abstract notions - such as 'Islam and governance' in this case - can be grasped, described, and shared. ${ }^{7}$ In fact, the late American philosopher Richard Rorty (1931-2007) once argued that the history of the arts, sciences, and morality, as well as the whole intellectual history of mankind could all be seen as the history of metaphor since they are connected to the history of language. ${ }^{8}$

It goes without saying that different theories of metaphors do exist. There are those who believe that metaphors are but ornaments of language. When used with verbal skill, they merely beautify language, but they do not add any content of knowledge. Some view metaphors as providing emotive values that could affect the moods of texts or conversations. Others, however, maintain that metaphors contain added values, because they create new contextual meanings which bring connotations of words to life while making thoughts of two different things interactive while supporting those thought by a single word. ${ }^{9}$

But what exactly does a metaphor do? In Rorty's opinion, tossing a metaphor into a conversation is like suddenly breaking off the conversation long enough to slap the interlocutor's face or to kiss him. Throwing it into a text is like using italics, illustrations or punctuations. In this sense, metaphors are used not to convey messages, but are ways to produce effects on the readers or interlocutors. ${ }^{10}$ If the effects are polemical, using metaphors could sensitise those involved to the politicising implications of discursive selection. Such a politicisation of figuration could either be in the direction of mystification and legitimation serving prevailing structures of authority, or in the direction of resistance especially towards the domain which has been naturalised by a familiar figuration which renders the issue unproblematic. ${ }^{11}$

If a metaphor is construed as the use of a familiar word in an unfamiliar setting, or an unfamiliar word in a familiar context, to produce effects which could change the ways one sees or understands the world by giving time to pause and open up enough space to think before a decision can be made, then it is not uncommon to find metaphors frequently used in different traditions where religious knowledge is regarded as sacred and the human minds, though intelligent, do have limits. 
Metaphorical language with all its power is frequently found in both the Qur'ān and the Prophetic traditions to produce different effects. Some scholars have even argued that Islamic political language is "full of metaphor"; though some of it may be dead, buried, or forgotten, quite a few are alive and used in everyday life. ${ }^{12}$ However, if this approach is to be used, what would be the metaphors for Islam and governance? And why?

\section{The Ship(s) and the Stranger(s) as Metaphors for Governance and Islam}

It should be noted that the term 'governance' was not new. It was used by King Henry IV (r. 1399-1413) to justify his usurpation of the English throne in 1399, declaring that his predecessors' failures resulted from "default of governance" and "undoying of good laws". ${ }^{13}$ In the twenty-first century, however, the notion of 'governance' originates from the need of economics and political science for a concept broad enough to accommodate diverse meanings in terms of the overall exercise of power not covered by the term 'government'. The idea of 'European governance' was initiated as the first priority of the European Commission's strategic objectives for the period 2000-05. In order to realise such objectives, the notion of 'governance' was suggested as a shift in focus from politics as 'who governs?' especially about half a century ago by Robert Dahl (b. 1915), one of today's most distinguished political scientists - to 'the how of governing', namely the ways in which decisions and policies are made and implemented. More importantly, 'European governance' as envisioned by the European Commission is not merely an account on how governing $i$, but on how governing for the new Europe with its contemporary problems affecting democracy such as alienation of citizens and loss of confidence in institutions and politics should be. The idea of 'good governance' with its five basic principles - openness, participation, accountability, effectiveness and coherence - is therefore suggested as a meaningful way to "connect Europe with its citizens". ${ }^{14}$ If the new Europe marks the shape of politics to come, then perhaps - as argued by the Swedish political scientist Jon Pierre, a leading author on governance - the world has entered "the era of economic globalisation, hollowing out of the state, decreasing legitimacy for collective solutions, and a marketisation of the state itself". ${ }^{15}$

Seen in this way, governing in a seemingly 'centre-less' society where there are many centres of power, linking numerous state actors at different levels - local, regional, national, or supranational - involves questioning legitimacy and accountability of existing structures. At a time when the power of sovereignty has become increasingly suspect, the magic of the nation-state is declining and the nature of the state itself is changing. The problem of governance is thus the question of how different peoples in various locations of power can be 'connected'. 
Though the meanings of the concept of governance are highly contested, they all point to the multiplicity of actors, terrains and different relationships among them in the process of governing, characterised by a much more pluralistic conceptualisation of power. ${ }^{16}$ When the state becomes a collection of networks with numerous actors, "with no sovereign actor being able to "steer or regulate", the main challenge for government is "to enable these networks and to seek out new forms of co-operation". ${ }^{17}$ This is one of the reasons why the problem of how to 'connect peoples of differences' in this new reality cannot be approached in terms of the 'command of a bureaucratic state' with its unitary concept of state and power, but more as 'control'.

In discussing the problem of governance in terms of 'control', construed as connecting people with a more pluralistic conceptualisation of power, some commentators use metaphors associated with 'ship'. They argue that the role of government should be to 'steer not row' because the Weberian model of bureaucracy has become bankrupted and should be replaced by 'entrepreneurial government'. The essence of such a government is that the state withdraws from government less rowing - and moves towards governance - more steering. ${ }^{18}$

There is a perfectly good reason why the 'ship' metaphor has been used time and again in discussing politics. Since politics is primarily about speaking and the use of language, it must dramatise itself. Most political expression is therefore metaphorical. In fact, the state, understood as the 'body politic', has been usually expressed as a ship because this metaphor lies behind the very word 'government' which comes from the Latin gubernaculum, referring to a rudder. ${ }^{19}$ This word can also be traced to an ancient Greek verb meaning to steer. ${ }^{20}$ In this sense, politics could be seen as the art of navigating or steering the ship of state.

In the sixth book of Plato's Republic, Glaucon asked Socrates: "How can it be good to say that the cities will have no rest from evils before the philosophers [...] rule in them?" (487e). ${ }^{21}$ Socrates replied that the question needs an answer given through an image. He also apologised to his interlocutor because his images came "from many sources, as the painters paint goatstags and such things by making mixtures" (488a). Then he said something peculiar: "Listen to the image so you may see $[\ldots]$ " (488a). ${ }^{22}$ For Plato, this is how a metaphor works as figurative language. Through words, the image is to be heard. But from hearing, it can then be seen.

More importantly, the image Socrates used is that of a ship where the ship owner is "deaf, short-sighted" and with little knowledge of seamanship. The sailors, without knowledge of the sea and the ship, were doing everything to have the owner turn the rudder to them. If they fail at persuasion, and others succeeded, they would either kill the others or throw them out. After successfully enchaining the ship owner, they rule the ship, "using what's in it; and drinking and feasting, they sail as such men would be thought likely to sail. Besides this, they praise and call 'skilled sailor,' 
'pilot', and 'knower of the ship's business' the man who is clever at figuring out how they will get the rule, either by persuading or by forcing the ship owner, while the man who is not of this sort they blame as useless" (488b-d). ${ }^{23}$

If politics is seen as conducting the 'ship of state', then steering is a proper metaphor for governance understood as how to navigate this ship. A crucial question would then be: what signs should be used to guide the steering? Socrates points out that the true captain who could sail the ship properly is someone who "pay[s] careful attention to year, seasons, heaven, stars, winds, and everything that's proper to the art, if he is really going to be skilled at ruling a ship" (488d). ${ }^{24}$ But here steering the ship as a metaphor leads to others: the year, seasons, heaven, stars and winds.

There are at least two important elements in reading these metaphors that are related to the act of navigating the ship of state. They are changes and guides. The stars and heavens are high up above and they appear to be fixed in the sky which serve to guide seamen from times immemorial. The winds blow in accordance with seasons, which, in turn, change throughout the year. Could it mean that in navigating the 'ship of state', the steersman steers under the guidance of ideals, distant beacons of excellence which most people aim at, and yet need to be aware of the changing realities which will be responsible for success or failures in reaching those ideals?

Although the 'ship' metaphor clearly reflects the notion of governance discussed above, in what ways is it connected to the Islamic imagination, if at all? Given the context of the desert, it should be noted that the metaphor used for politics in Arabic is not sailing or steering the ship, but training a horse. In those languages of the Muslim world that have some footing in Arabic, it is siyāsah which denotes 'politics'. Deriving from Classical Arabic, the respective verb means 'to groom' or 'to train a horse'. ${ }^{25}$

But the ship metaphor has also been used in Islam, both in the Qur'ān and the hadìth. It is often found in the story of Noah and the Flood. ${ }^{26}$ For example, in the Qur'ān (23:27-8) we read:

So We inspired him (with this message): "Construct the Ark within Our sight and under Our guidance: then when comes Our Command, and the fountains of the earth gush forth, take thou on board pairs of every species, male and female, and thy family - except those of them against whom the Word has already gone forth: And address Me not in favour of the wrong-doers; for they shall be drowned (in the Flood). And when thou hast embarked on the Ark - thou and those with thee, - say: 'Praise be to Allah, Who has saved us from the people who do wrong."”

The words 'ship' or 'Ark' used above are literal and not metaphorical. Unless the whole story of Noah and the Flood is understood as a metaphor, the 'ship' or the 'Ark' in these verses denote the vessel God commands Noah to build to save living beings from the great Flood. The people saw what Noah did and they laughed 
at him. ${ }^{27}$ But during the Flood, Noah did not need to "steer the ship" because the whole world was under water and there was no place to go, no need to go anywhere. But 'the ship(s)' which appear in the Qur'ān elsewhere and which are not directly related to the story of Noah are different. As metaphors, they lead the readers into an unfamiliar space. For example, in the Qur'ān (42:32-3) we read:

And among His Signs are the ships, smooth-running through the ocean, (tall) as mountains. If it be His Will He can still the Wind: then would they become motionless on the back of the (ocean). Verily in this are Signs for everyone who patiently perseveres and is grateful.

That the ship(s) appears in this verse as signs is clear. But there are other signs in the verses which immediately precede it. These signs are: "the creation of the heavens and earth", and "all the living creatures" (Qur'ān 42:29-30). Compared to other signs, the ship(s) is most human since it is manmade. This manmade sign then signifies God's Mercy because ships are used to "plough their courses" so that humans can enjoy the fruits of the sea in order to eat and to preserve life and to use some as ornaments to adorn themselves. The Qur'ān (35:12) says:

Nor are the two bodies of flowing water alike - the one palatable, sweet, and pleasant to drink, and the other, salt and bitter. Yet from each (kind of water) do ye eat flesh fresh and tender, and ye extract ornaments to wear; and thou seest the ships therein that plough the waves, that ye may seek (thus) of the Bounty of Allah that ye may be grateful.

Yet, this man-made artefact is not entirely under human command. They depend on the winds and God can make the wind stay still and therefore render the ship(s) motionless. The Qur'ān (10:22) says:

He it is Who enableth you to traverse through land and sea; so that ye even board ships; they sail with them with a favourable wind, and they rejoice thereat; then comes a stormy wind and the waves come to them from all sides, and they think they are being overwhelmed: they cry unto Allah, sincerely offering (their) duty unto Him saying, "If thou dost deliver us from this, we shall truly show our gratitude!"

The Qur'ān (17:66) also states:

Your Lord is He That maketh the Ship go smoothly for you through the sea, in order that ye may seek of his Bounty. For he is unto you most Merciful.

Steering the $\operatorname{ship}(s)$ - from an Islamic perspective - requires that humans not only gaze at the stars and listen to the winds, as Socrates explained in The Republic, but also to be humble before God, knowing that the clear night sky can turn cloudy and that a breeze can easily become a fierce storm.

The conflation of the metaphorical and the real of the ship(s) finds expression in the early Muslims' practice in Southeast Asia. In the fifteenth century, the Malacca 
sultanate used a form of shari 'ah-based law, called the Undang undang Laut Melaka (the Maritime Laws of Malacca), as their laws of the sea. These laws entirely consisted of rules, regulations, procedures and codes of conduct to be used at sea. Among other things, these laws considered the captain of a ship, the imām (leader), and his subjects as followers (ma'mūm). ${ }^{28}$

The ship as a metaphor for governance is therefore relevant from an Islamic perspective. Tossing 'the ship' into a set of signs God created which include heavens, earth and all the living creatures is clearly juxtaposing something worldly and less abstract amidst something magical and cosmic. By throwing in the 'familiar' with the 'unfamiliar', the ship metaphor opens up space for a rethinking of what it means to govern, and how to govern with all its limitations. It does not take away from the original meanings which constitute governance but enriches it with a strong sense of the limitations of governance.

If 'the ship' could be used as a metaphor for governance both from political science scholarship as well as from an Islamic perspective, what could possibly be a metaphor to be used for Islam?

According to 'Alī b. Abī Țâlib (d. 661), the fourth of the early caliphs, Prophet Muhammad's guidance in life could be summed up as follows: "Do for this world as if to live forever and for the next as if to die upon tomorrow." 29 This teaching can be divided into two parts. First, believing in the next world as an article of faith and yet living this life as a gift from God, a Muslim has 'to do' something for both worlds. Second, doing for both worlds takes a radical form when the attitude towards living and dying is reversed. A Muslim knows he/she would not live forever and death comes to everyone. Such an attitude is also in line with the Qur'ān (21:34). Yet here the Prophet teaches a Muslim to do his/her utmost for this world, knowing that with every moment everyone lives under the shadow of death and therefore needs to prepare for the hereafter to the best of his/her ability.

The advice 'to do for this world and the next' is contingent upon an understanding of what it means 'to be in this world'. The Prophet once said: "Be in this world as a stranger or a passer-by" (al-Bukhārī, hadīth no. 8,425). ${ }^{30}$ It was also narrated by Abū Hurayrah that the Prophet once said: "Islam began as something strange and it will revert to its [old position] of being strange; so, good tidings for the strangers" (Muslim, hadìth no. 270). ${ }^{31}$

Islam will be seen as strange in this world and a Muslim will always be a stranger in it. As a result, Muslims and Islam will be subjected to misunderstanding, appearing suspect and often feared. More importantly, for the Muslims themselves, the metaphor of a perpetual stranger reflects a sense of unfamiliarity with the surrounding world. A stranger will be in a state of awakening in walking through unfamiliar terrains. It is the sense of wonder at the marvels of the world that dominates the stranger at the moment of encountering the unfamiliar - rather 
than fixed judgments of them. Without such a fixation, a stranger might be in a position to choose from a number of alternatives that are normally curtailed by the chain of familiarity.

Perhaps this is why in the Laws - one of Plato's most significant works, which is much more than a legal theory of state, but embraces the cosmic order, governance as well as cultural forms - Socrates' direct existential appeal has been withdrawn. Written towards the end of Plato's life, arguably with more experiences with the life of the spirit as a fine-tuning of the soul with the divine Measure, Plato replaced the familiar Socrates with 'an Athenian stranger'. It is this stranger with his knowledge who develops a plan and the motivations for political institutions inspired by the Divine that will be "bearable to men as they are". 32

Thinking through the issues of governance and Islam, where would the metaphors of the ship(s) and the stranger lead to? In what ways would these metaphors contribute to governance which would be "bearable to men as they are"?

\section{Conclusion: Metaphorical Illuminations and 'Soft Governance?'}

In a dialogue between Richard Rorty and Gianni Vattimo on 'The Future of Religion', held in Paris on 16 December 2002, the two philosophers agreed that humanity has entered "the age of interpretation" where there are no more strong reasons either to be an atheist refusing religion or to be a theist refusing science. Faith has arrived at a point where it could accommodate these dualisms without recognising any reason for conflict. Motivated by the notion of 'the death of God', the secularisation of the sacred has signified the rebirth of religion in the third millennium. It is secularisation which renders philosophical questions about the nature of God useless. Because of the weakness of human reason it is not clear what it actually means to affirm or deny His existence, thus placing God's existence outside of history. ${ }^{33}$

I am curious as to the place of Islam in such a 'future'. Is this portrait of 'the future of religion' also 'the future of Islam'?

Towards the end of their dialogue, Vattimo asked Rorty: "What can we do with people who apparently do not share civic responsibility either inside our society or outside? What happens when we arrive at a place which refuses us, like some parts of the Islamic world; what do you think we should preach to them?" Rorty, the eminent philosopher of postmodernity, replied: "[...I]t seems to me that the idea of a dialogue with Islam is pointless [...]. With luck, the educated middle class of the Islamic countries will bring about an Islamic enlightenment, but this enlightenment will not have anything to do with a 'dialogue with Islam"' 34

Rorty's argument can be easily called into question in the age of diversity of interpretations and contested identities. For example, what does it mean to engage in a 'dialogue with Islam'? Since when in our century does someone speak on behalf 
of 'Islam'? Or can there be anyone who represents 'Islam' with authority and who is accepted by Muslims all over the world? Is there only one 'Islam' or are there many 'Islams' out there in different contexts?

More importantly, these two philosophers were discussing the future of Christianity in 'the West' with its particular historical context and not the future(s) of all religions. ${ }^{35}$ It is therefore safe to assume that the future of religions in their plurality could take many forms, resulting from each one's particular history and the ways in which these histories shape and reshape one another. As a result, the routes through which people from various religious traditions enter "the age of interpretations' have been different. From basic Islamic belief where the world is divided between the Creator and the created, the weakness of human reason is well understood. Faith may be rejuvenated not by accommodating dualisms but by reaffirming a set of religious identities alongside, as well as over and above, other sets including the national or the professional spheres. Moreover, it is not the 'secularisation of the sacred' which marks the future of Islam, but the finding of ways in which both the secular and the sacred could exist side by side. What takes place at present is that the movement into sacred space by the secular co-exists with the ways in which the secular has also become sacred. Fast-food outlets in modern Muslim societies, therefore, have to display a 'halāl' sign, indicating that properly slaughtered meat is offered to the believers/consumers. Modern banking and insurance institutions have to provide services that are in line with Islamic injunctions.

But how is it possible that someone such as Rorty would arrive at the surprising conclusion that dialogue with 'Islam' is 'pointless'? In addition to a critique of Rorty's perspective, I would argue that it is also important to look at how some extremist Muslims tend to focus on the most rigid form of governance - for example in terms of punishment - which is partly responsible for the way Islam is seen today by many non-Muslims.

In the work Fiqh al-sunnah - when dealing with hudüd and after having gone through juristic opinions substantiated by doctrinal readings on what to do with apostates - the author arrives at the conclusion that apostasy is supposed to be punishable by death. The reasons given are much more interesting, however. First, the author argues a person has attained perfection by having 'accepted' Islam. However, if he/she returns to the 'lowest' level, then such a life is 'not worth living' since it would be a life without honour and purpose, and therefore the death penalty would be appropriate. Second, he argues that since Islam is a 'total system', there would be a need to protect this 'totality' by forbidding anyone from leaving the 'faith' - read: 'community', since this would undermine or dissolve it. In this sense, 'leaving the faith' is seen as a cancellation of the system, a betrayal of the community which is not unlike treason in a nation-state which too is generally punishable by death (well, at least in some more totalitarian settings). ${ }^{36}$ 
In opposition to this, however, I argue that using the metaphors of the 'ship' and 'the stranger', governance as seen from Islamic perspective and metaphorically informed, cannot be restrictive nor harsh, supposedly 'orthodox' traditional juristic opinions notwithstanding. Certainly, it is 'soft governance', understood as an attempt to meaningfully connect a multiplicity of actors from different terrains with complex relationships among them in the process of governing with a much more pluralistic conceptualisation of power, which should be explored.

The metaphors of the 'ship' and the 'stranger' may help to illuminate the notion of 'soft governance' for the following reasons.

First, it was said that using metaphors means introducing the unfamiliar to the familiar, or vice versa, in order to produce effects on the readers/interlocutors. But more importantly, the effects produced by metaphors create a space that is necessary for any dialogue among peoples with differences and that is conducive to efforts in creating meaningful connections between them.

Second, the metaphors point to highly limited governance, especially in terms of the power to punish, due to the limits which come from the circumstance of being human. The most skilful captain and his sailors on a ship are those who know the capacity of their ship and their own limitations. For example, soft governance will influence a choice of punishment that will be judged within the limits of human reason and understanding and thereby opens up the possibility of a much larger space for the accused to redeem oneself.

Third, a ship is made to sail at sea. Though predictable, the rhythms of the sea, the blow of the winds, and the brightness of the night sky can all change quickly and thus upset any certainty. Facing such a volatility of reality, soft governance allows for the realistic changes in policies and practices to take place with the possibility of accommodating genuine differences.

Fourth, ships continue to sail the seas. Their captains steer their ships. The sailors continue to perform their functions and passengers continue to travel on them. All this happens not because they do not know that humans do have limits in controlling the ships, nor are they certain about the oceans, but because, in some ways, they hope that everything will proceed on its proper course. For Muslims, it is the belief in God's infinite mercy which makes life with all its human limitations and uncertainties bearable - and therefore the engaging with others in dialogue possible and even desirable.

\section{Notes}

1. See a more recent case of Abdul Rahman, an Afghan who converted to Christianity and had to move to Italy after a furore over his trial under Islamic sharī'ah law, as reported in Bangkok Post on 10 April 2006. See also a useful discussion on this very issue in Zainah Anwar, "Law-Making in the Name of Islam: Implications for Democratic Governance", in: K.S. Nathan and Mohammad 
Hashim Kamali (eds), Islam in Southeast Asia: Political, Social and Strategic Challenges for the 21st Century (Singapore: Institute of Southeast Asian Studies, 2005), 129-30.

2. Jan Stark, "Contesting Models of Islamic Governance in Malaysia and Indonesia", Global Change, Peace and Security 16, no. 2 (June 2004), 115-31.

3. Judith Nagata, "Alternative Models of Islamic Governance in Southeast Asia: Neo-Sufism and the Arqam Experiment in Malaysia", Global Change, Peace and Security 16, no. 2 (June 2004), 99-114.

4. Literally meaning 'limits', or 'restrictions', a term often used in Islamic literature for the limits of acceptable behaviour and the punishments for serious crimes. In Islamic law, hudüd usually refers to the class of punishments that are fixed for certain crimes that are considered to be 'claims of God'. They include theft, fornication, consumption of alcohol, and apostasy.

5. Anwar, "Law-Making", 129, 124, and 128. The quoted passage is on p. 128.

6. Ibid., "Law-Making", 124-32.

7. Guy Deutscher, The Unfolding of Language: An Evolutionary Tour of Mankind's Greatest Invention (New York: Metropolitan Books, 2005), 117.

8. Richard Rorty, Contingency, Irony and Solidarity (Cambridge and New York: Cambridge University Press, 1990), 16.

9. For a discussion of different theories of metaphors see Janet Martin Soskice, Metaphor and Religious Language (Oxford: Clarendon Press, 1987), 24-53.

10. Rorty, Contingency, 18.

11. Michael J. Shapiro, "Literary Production as Politicizing Practice", in: Michael J. Shapiro (ed.), Language and Politics (New York: New York University Press, 1984), 231.

12. See, for example, Bernard Lewis, The Political Language of Islam (Chicago and London: The University of Chicago Press, 1991), 11.

13. David Richards and Martin J. Smith, Governance and Public Policy in the United Kingdom (Oxford: Oxford University Press, 2002), 14.

14. Angela Liberatore, "Governance and Democracy: Reflections on the European Debate", in: Surendra Munshi and Biju Paul Abraham (eds), Good Governance, Democratic Societies and Globalisation (New Delhi, Thousand Oaks, and London: Sage Publications, 2004), 71-4. The quoted passage is on p. 74.

15. Cited in Richards and Smith, Governance, 14.

16. Ibid., 19.

17. Ibid.

18. Ibid., 18.

19. Kenneth Minogue, Politics: A Very Short Introduction (Oxford and New York: Oxford University Press, 1995), 83.

20. Lewis, The Political Language of Islam, 11.

21. Plato, The Republic of Plato, transl. Allan Bloom (New York and London: Basic Books Inc., 1968), 167.

22. Ibid., $167-8$.

23. Ibid., 168.

24. Ibid.

25. Lewis, The Political Language of Islam, 11.

26. Translations from the Qur'ān throughout my article are from Abdullah Yusuf Ali, The Meaning of the Holy Qur'an (new edition with revised translation and commentary) (Brentwood MA: Amana Corporation, 1991).

27. Qur'ān 11:38-9.

28. A.B. Shamsul, "Islam Embedded: Moderate Political Islam and Governance in the Malay World", in: Nathan and Kamali (eds), Islam in Southeast Asia, 112.

29. Martin Lings, Muhammad: His Life Based on the Earliest Sources (Rochester VT: Inner Traditions International, Ltd, 1983), 325.

30. Ibid., 325. 
31. Imām Muslim, Șaḥịh Muslim, transl. Abdul Hamid Siddiqi (Lahore: Sh.Muhammad Ashraf, 1978), $1: 86$.

32. Eric Voegelin, Plato (Baton Rouge: Louisiana State University Press, 1966), 227.

33. Santiago Zabala, "Introduction: A Religion Without Theists or Atheists", in: Richard Rorty and Gianni Vattimo, The Future of Religion, ed. Santiago Zabala (New York: Columbia University Press, 2005), 1-27.

34. Ibid., 72-3.

35. It should be pointed out that both 'the future' and 'religion' in the title of the book, edited by Zabala and cited above, on these philosophers' dialogue are all in singular.

36. Sayyid Sabik, Fiqh-us-Sunnah (Bangkok: Arab Universities Alumni Association, 2002), 4:158-9 (Thai transl. from Arabic). 